\title{
PENINGKATAN PENGETAHUAN DAN DETEKSI DINI PENYAKIT HIV PADA REMAJA DILINGKUNGAN POLITEKNIK HARAPAN BERSAMA KOTA TEGAL
}

\author{
Nilatul Izah ${ }^{1}$, Juhrotun Nisa², Evi Zulfiana ${ }^{3}$, Meyliya Qudriani ${ }^{4}$, Seventina Nurul Hidayah ${ }^{5}$, \\ Mutiarawati $^{6}$ \\ 1,2,3,4,5,6 Diploma III Kebidanan Politeknik Harapan Bersama \\ e-mail:nilaizah12@gmail.com
}

\begin{abstract}
Abstrak
Perkembangan permasalahan Human Immunodeficiency Virus (HIV) danAcquired Immune Deficiency Syndrome (AIDS) semakin lama semakin mengkhawatirkan baik dari sisi kuantitatif maupun kualitatif. Usia remaja merupakan usia yang paling rentan terinfeksi HIV/AIDs dan Penyakit Menular Seksual (PMS) lainnya. Bahkan, dalam jangka waktu tertentu, ketika perempuan remaja menjadi ibu hamil, maka kehamilannya dapat mengancam kelangsungan hidup janin/bayinya. Data Dinas Kesehatan Kota Tegal menyebutkan jumlah penderita HIV/AIDS sebanyak 230 dengan rincian 111 menderita HIV, 119 AIDS, dan 44 meninggal dunia. 61,1 persen dari total jumlah penderita HIV/AIDS yang tercatat masih tergolong usia produktif antara 20 hingga 39 tahun. Data tersebut terbagi menjadi dua, yakni 31,5 persen dengan usia berkisar 20-29 tahun dan 29,6 persen lainnya tergolong usia produktif 30-39 tahun. Kegiatan pengabdian masyarakat inidilakukan untuk meningkatkan pengetahuan remaja mengenai penyakit menular seksual dan deteksi dini terhadap penyakit HIV. Kegiatan dilakukan dengan cara memberikan informasi dan pendidikan kesehatan terutama tentang penyakit menular seksual dan pemeriksaan HIV. Kegiatan ini dilakukan pada mahasiswa di lingkungan Politeknik Harapan Bersama yang terdiri dari 7 program studi. Hasil pengabdian masyarakat ini terjadi peningkatan pengatahuan tentang penyakit menular seksual dan hasil pemeriksaan HIV negatif. .
\end{abstract}

Kata kunci : Pengetahuan, Deteksi Dini, Penyakit Menular Seksual, HIV

\section{PENDAHULUAN}

Perkembangan permasalahan Human Immunodeficiency Virus (HIV) danAcquired Immune Deficiency Syndrome (AIDS) semakin lama semakin mengkhawatirkan baik dari sisi kuantitatif maupun kualitatif. Walaupun secarageografi, yang semula diharapkan dapat menghambat perkembangan jumlahOrang Dengan HIV dan AIDS (ODHA) di dunia namun pada kenyataannyadalam kurun waktu 20 tahun terakhir jumlahnya telah mencapai lebih dari 60juta orang dan 20 juta diantaranya telah meninggal. Tidak mengherankan bilapermasalahan $H I V$ dan $A I D S$ telah menjadi epidemi di hampir 190 negara. 
Usia remaja merupakan usia yang paling rentan terinfeksi HIV/AIDs dan Penyakit Menular Seksual (PMS) lainnya. Bahkan, dalam jangka waktu tertentu, ketika perempuan remaja menjadi ibu hamil, maka kehamilannya dapat mengancam kelangsungan hidup janin/bayinya. Indikator-indikator untuk masalah kesehatan reproduksi dipresentasikan pada bagian ini. Informasi mengenai masalah kesehatan reproduksi, selain penting diketahui oleh para pemberi pelayanan kesehatan, pembuat keputusan, juga penting untuk para pendidikan dan penyelenggara program bagi remaja, agar dapat membantu menurunkan masalah kesehatan reproduksi remaja.

Penyakit menular seksual merupakan suatu penyakit yang mengganggu kesehatan reproduksi yang muncul akibat dari prilaku seksual yang tidak aman. Penyakit Menular Seksual (PMS) merupakan penyakit anak muda atau remaja, karena remaja atau anak muda adalah kelompok terbanyak yang menderita penyakit menular seksual (PMS) dibandingkan kelompok umur yang lain.

Data dari Komisi Penanggulangan AIDS Nasional, faktor resiko terbesar kasus AIDS adalah IDU (Injecting Drug User) sebesar 49,86\%, 41,86\% heteroseksual, $3,90 \%$ homoseksual, $2,59 \%$ transmisi perinatal, $1,70 \%$ dari transfusi darah dan $2,59 \%$ tidak diketahui.

Data Dinas Kesehatan Kota Tegal menyebutkan jumlah penderita HIV/AIDS sebanyak 230 dengan rincian 111 menderita HIV, 119 AIDS, dan 44 meninggal dunia. 61,1 persen dari total jumlah penderita HIV/AIDS yang tercatat masih tergolong usia produktif antara 20 hingga 39 tahun. Data tersebut terbagi menjadi dua, yakni 31,5 persen dengan usia berkisar 20-29 tahun dan 29,6 persen lainnya tergolong usia produktif 30-39 tahun.

Konseling bertujuan untuk mencegah penularan $H I V$, mengubah perilaku ODHA, pemberian dukungan yang dapat menumbuhkan motivasi mereka, meningkatkan kualitas hidup ODHA. Berdasarkan hasil penelitian terhadap pasien HIV/AIDS di RSU Dr.Soetomo yang dilakukan oleh Patola L.N (2005) diketahui bahwa VCT efektif dalam mengubah pengetahuan, sikap, tindakan pasien beresiko tinggi untuk melakukan tes $H I V$ dimana $100 \%$ responden penelitianya bersedia melakukan tes $H I V$ setelah diberikan konseling.

Berdasarkan hal tersebut kami akan melakukan pendidikan kesehatan guna 
meningkatkan pengetahuan dan melakukan pemeriksaan untuk deteksi dini penyakit menular seksual pada remaja dilingkungan Politeknik Harapan Bersama Kota Tegal yang meliputi pemeriksaan HIV.

Masyarakat terutama remaja adalah bagian penting dan strategis dalam penanggulangan HIV/AIDS. Karena masyarakat dapat menjadi objek sebagai dampak HIV/AIDS sekaligus dapat menjadi subjek sebagai pelaku penanggulangan HIV/AIDS. Sehubungan dengan peran masyarakat sebagai subjek status pengetahuan dan kesadaran HIV/AIDS pada masyarakat perlu ditingkatkan. Masyarakat juga perlu mengetahui status kesehatan mereka khusunya bebas dari infeksi HIV sehingga perlu adanya pemeriksaan HIV

\section{METODE}

Kegiatan pengabdian kepada masyarakat mengenai peningkatan pengetahuan remaja tentang penyakit menular seksual serta deteksi dini penyakit HIV ini diberikan kepada mahasiswa dilingkungan Politeknik Harapan Bersama yang terdiri dari 7 program studi yaitu program studi kebidanan, informastika, akutansi, farmasi, komputer, elektronika, dan program studi teknik mesin.

Kegiatan pengabdian kepada masyarakat ini didanai oleh mitra yaitu dari Dinas Kesehatan Kota Tegal Program Pencegahan Penyakit Menular. Proses pelaksanaan kegiatan pengabdian melalui beberapa tahap, yaitu:

1. Koordinasi dengan bagian Program Pencegahan Penyakit Menular Dinas Kesehatan Kota Tegal

2. Mengurus perijinan dengan Politeknik Harapan Bersama

3. Koordinasi dengan bagian kemahasiswaan di semua program studi

4. Memberikan informasi kepada mahasiswa

5. Mengumpulkan peserta yang terdiri dari mahasiswa dari 7 program studi

Kegiatan Pengabdian Masyarakat dalam bentuk pemberian pendidikan kesehatan dan pemeriksaan HIV dilaksanakan sebanyak 2 pertemuan. Pertemuan pertama pada tanggal 27 November 2017 rapat dan persiapan pelaksanaan kegiatan, pertemuan kedua pada tanggal 28 November 2017 pemberian pendidikan kesehatan serta pemeriksaan sebagai deteksi dini remaja terhadap penyakit HIV. Kegiatan ini dilakukan di ruang kelas Politeknik Harapan Bersama ruang A3.1. 

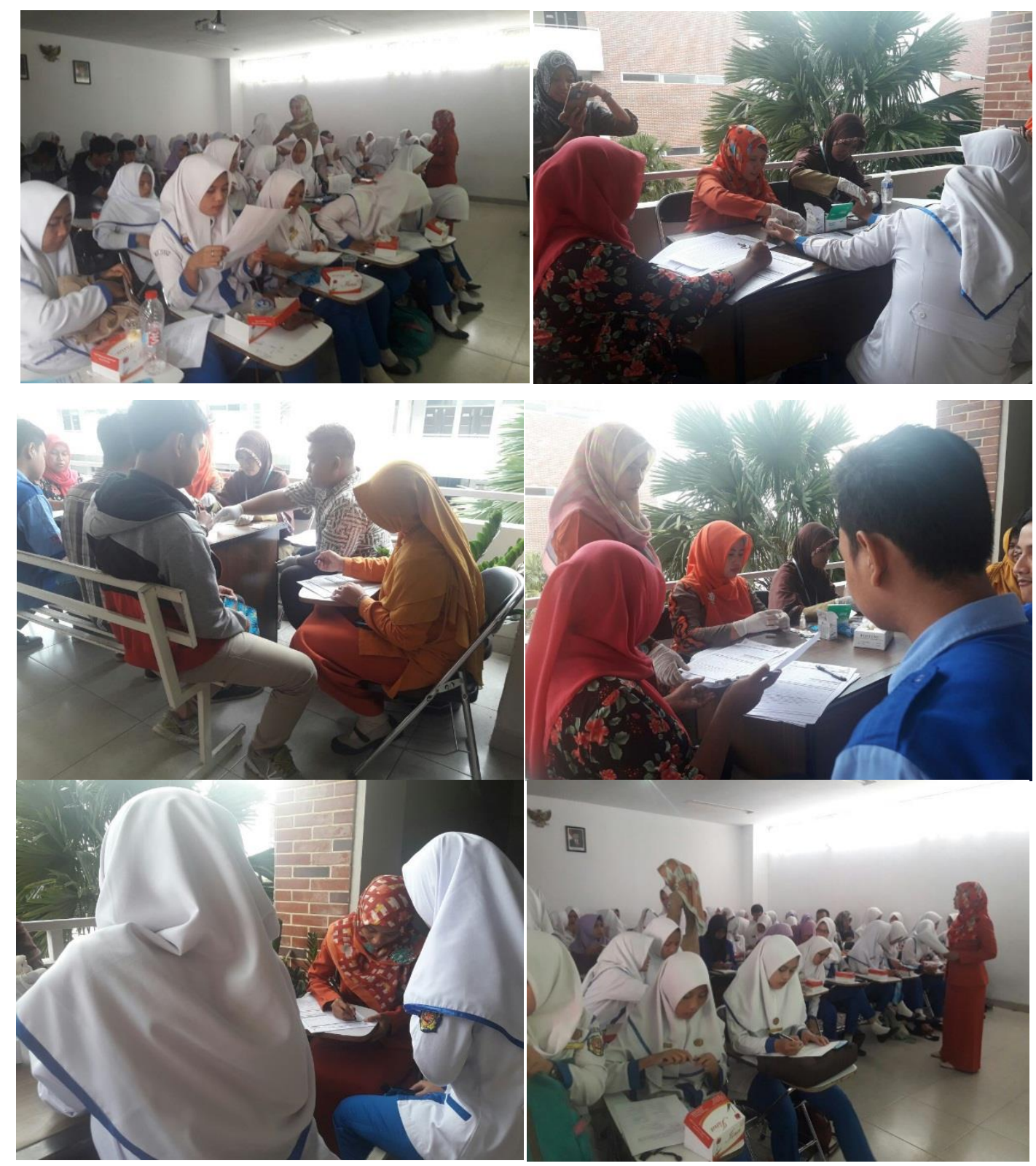

Gambar: Pengabdian masyarakat pengabdian peningkatan pengetahuan dan deteksi dinipenyakit HIV

\section{HASIL DAN PEMBAHASAN}

Kegiatan pengabdian kepada masyarakat yang dilaksanakan pada mahasiswa dilingkungan Politeknik Harapan Bersama diawali dengan membagikan kuesioner untuk menilai tingkat pengetahuan mahasiswa tentang penyakit menular seksual. Setelah mahasiswa mengisi kuesioner dilakukan pendidikan kesehatan tentang penyakit menular seksual, kegiatan tidak hanya pemberian pendidikan kesehatan, 
dilakukan juga pemeriksaan HIV untuk mengetahui status kesehatan mahasiswa tentang HIV.

Tabel 1. Peningkatan pengetahuan remaja sebelum dan setelah pendidikan kesehatan

\begin{tabular}{|l|c|c|}
\hline \multicolumn{1}{|c|}{ Tingkat Pengetahuan } & Baik & Kurang \\
\hline Sebelum pendidikan kesehatan & 18 & 42 \\
\hline Setelah pendidikan kesehatan & 36 & 24 \\
\hline
\end{tabular}

Gambar 2. Grafikpeningkatanpengetahuansebelumdansesudahpenyuluhan

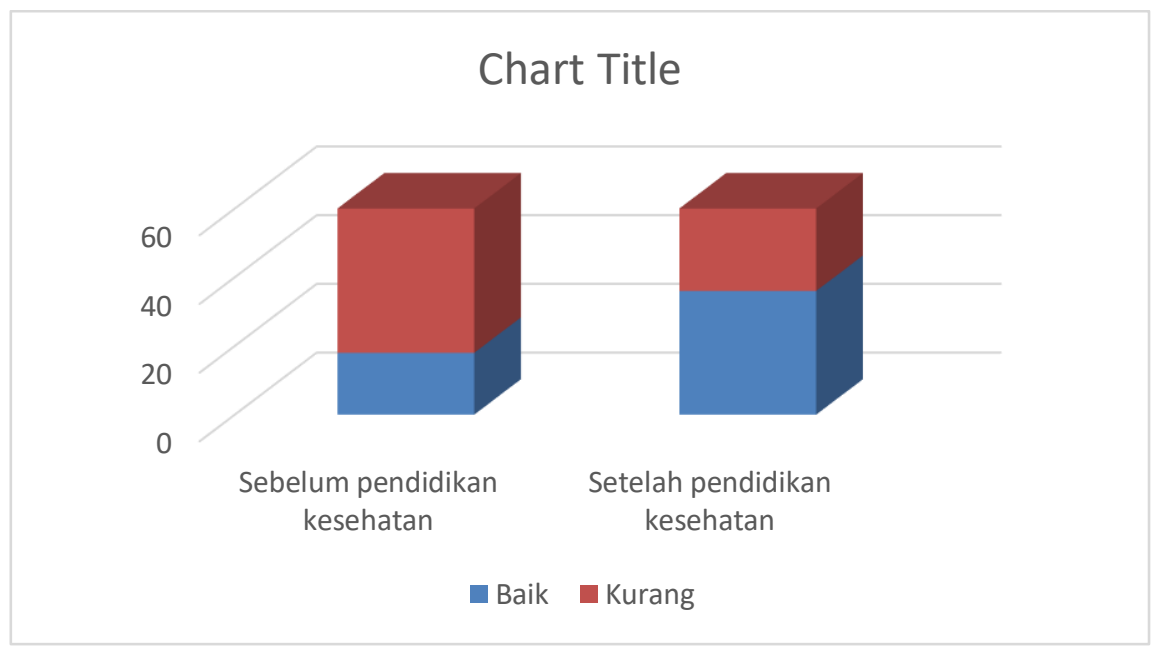

\section{KESIMPULAN}

Kegiatan pendidikan kesehatan yang dilakukan dengan cara penyuluhan serta deteksi dini terhadap penyakit menular seksual ini merupakan salah satu cara untuk memberikan infomasi, meningkatkan pengetahuan serta deteksi dini terhadap penyakit menular seksual yang efektif. Dengan diberikannya pendidikan kesehatan maka akan terbentuk perilaku sehat khususnya bagi para remaja dilingkungan Politeknk Harapan Bersama. Kegiatan pengabdian masyarakat ini diikuti oleh 78 peserta yang merupakan mahasiswa dilingkungan Politeknik Harapan Bersama yang berasal dari 7 program studi. 


\section{SARAN}

Pendidikan kesehatan sekaligus deteksi dini untuk remaja tentang penyakit menular seksual sangat perlu di lakukan, hal ini dilakukan sebagai upaya untuk mencegah sekaligus pengobatan jika ditemui adanya masalah terhadap penyakit menular seksual pada remaja. Selain itu perlu adanya pelatihan untuk para remaja sehingga informasi dapat diteruskan oleh para kader terhadap teman sebayanya.

\section{DAFTAR PUSTAKA}

[1]. Departemen Kesehatan RI, Situasi HIV/AIDS di Indonesia tahun 1987-2006, 2007.

[2]. WHO (2014). HIV-AIDS. Tersedia pada: http://www.who.int/topics/hiv_aids/en/ [Diakses tanggal 31 Agustus 2017]

[3]. Kemenkes RI, Statistik Kasus HIV/ AIDS di Indonesia, Jakarta: Kemenkes RI, 2014.

[4]. Notoatmodjo, S, Pendidikan dan Perilaku kesehatan, Cetakan 2 Jakarta:PT. Rineka Cipta, 2007.

[5]. Dinas Kesehatan Kota Tegal, Profil Dinask Kesehatan Kota Tegal, 2017.

[6]. Handayani S, Perbandingaan Efektifitas Pemberian Informasi Melalui Buku Cerita Bergambar (Komik) Versi BKKBN dengan Media Leaflet, GASTER. Vol. 7. No. 1. Februari 2010.

[7]. Cahyono MD, Pengaruh Penyuluhan Kesehatan Terhadap Pengetahuan dan Sikap Siswa SMA 2 Sukoharjo Tahun 2013, [Skripsi Ilmiah], Surakarta: Fakultas Ilmu Kesehatan UMS, 2013. 